\title{
Puntius rohani (Teleostei: Cyprinidae), a new species of barb in the Puntius filamentosus group from the southern Western Ghats of India
}

\author{
K. Rema Devi ${ }^{1}$, T.J. Indra ${ }^{2}$ \& J.D. Marcus Knight ${ }^{3}$ \\ 1, 2 Zoological Survey of India, Southern Regional Centre, 100, Santhome High Road, Chennai, Tamil Nadu 600028, India \\ ${ }^{3}$ Flat 'L', Sri Balaji Apartments, $7^{\text {th }}$ Main Road, Dhandeeswaram, Velachery, Chennai, Tamil Nadu 600042, India \\ Email: ${ }^{1}$ remadevi_zsi@yahoo.com; ${ }^{3}$ jdmarcusknight@yahoo.co.in
}

\begin{abstract}
Puntius rohani, a new species of cyprinid fish, is described from the Kanyakumari District, southern India. This species can be distinguished from the other members of the Puntius filamentosus Group by the combination of the following characters: the absence of vertical black bands near the tips of the caudal fin; the presence of an elongate black club-shaped blotch 1.5 scales high extending from the 12-13 ${ }^{\text {th }}$ lateral-line scales to the caudal-fin base; and possessing 2-3+6-9 gill rakers on the first gill arch, 21-23 lateral-line scales, seven predorsal scales, $1 / 24+1+3-31 / 2$ scales in transverse line from the dorsal-fin origin to the mid-ventral scale row, and $2-2 \frac{1}{2}$ scales between the lateral line and the pelvic-fin origin.
\end{abstract}

Keywords: Fish, new species, Puntius filamentosus group, Western Ghats.

Date of publication (online): 26 August 2010 Date of publication (print): 26 August 2010 ISSN $0974-7907$ (online) | 0974-7893 (print)

Editor: Annonymity requested

Manuscript details:

Ms \# 02505

Received 07 July 2010

Final received 30 July 2010

Finally accepted 02 August 2010

Citation: Devi, K.R., T.J. Indra \& J.D.M. Knigh (2010). Puntius rohani (Teleostei: Cyprinidae), a new species of barb in the Puntius filamentosus group from the southern Western Ghats of India. Journal of Threatened Taxa 2(9): 1121-1129.

Copyright: @ K. Rema Devi, T.J. Indra \& J.D. Marcus Knight 2010. Creative Commons Attribution 3.0 Unported License. JoTT allows unrestricted use of this article in any medium for non-profit purposes, reproduction and distribution by providing adequate credit to the authors and the source of publication.

For Author Details and Author Contribution see end of this article.

Acknowledgements: We wish to thank the Director, Zoological Survey of India, Kolkata and the Officer-In-Charge, Southern Regiona Centre for the facilities provided. We also wish to thank S. Prabakaran, J.C. Dhas and R.J. Ranjit Daniels for the fish collections. We also thank A.B. Thiruvengadam and K. Muthukumar for helping us acquire samples from Vaigai Dam and Tamiraparani River. Our thanks are due to Beta Mahatvaraj for providing us with the photograph of Puntius exclamatio, to G Sankar for the photograph of the holotype and D. Senthil for the GPS data. Finally, we thank the reviewers for their excellent review and meticulous correction of the manuscript.

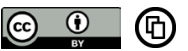

OPEN ACGESS | FREE DOWNLOAD

\section{INTRODUCTION}

The cyprinid fishes of the Puntius filamentosus group presently comprise seven species, five of which are endemic to India: Puntius arulius (Jerdon), P. assimilis (Jerdon), P. exclamatio Pethiyagoda \& Kottelat, P. filamentosus (Valenciennes) and $P$. tambraparniei (Silas), and two to Sri Lanka: $P$. singhala (Duncker) and P. srilankensis (Senanayake). These barbs are characterized by adult males developing filamentous extensions to the dorsal-fin branched rays and a juvenile colour pattern consisting of three black bars on the side of the body (Pethiyagoda \& Kottelat 2005a). This group of fishes was last reviewed by Pethiyagoda \& Kottelat (2005a), who in addition to describing a new species from southern India, revalidated several nominal species until then buried in the synonymy. These authors also drew attention to a fish illustrated as a "colour variety" of Puntius filamentosus from Periyakulam reservoir, Kanyakumari District, Tamil Nadu by Indra (1992), and suggested that it could represent an undescribed species. Recent surveys of Kanyakumari Wildlife Sanctuary resulted in fresh collections of this fish, which is described here as Puntius rohani, a new species.

\section{MATERIALS AND METHODS}

The material for the present study is based mostly on recent collections from the Kanyakumari Wildlife Sanctuary (KWS) during $2008-09$ by scientists of the Southern Regional Centre of the Zoological Survey of India, and specimens from earlier surveys in the collections of the Centre. The collection sites are shown in Fig. 1. The specimens are registered in the reserve collections of the Zoological Survey of India, Southern Regional Centre, Chennai (ZSI/SRS) and Zoological Survey of India, Western Ghats Regional Centre, Kozhikode (ZSI / WGRC). Measurements were made with dial calipers to the nearest $0.1 \mathrm{~mm}$ (except for the largest measurements, viz. total length (TL) and standard length (SL), which were measured with a ruler to the nearest $1 \mathrm{~mm}$ ). Quantification of characters follows Pethiyagoda \& Kottelat (2005a) except for length of maxilla, which is measured from the tip of the upper jaw to the 
posterior margin of the maxilla. Subunits of the head are expressed in proportions of both head length $(\mathrm{HL})$ and standard length (SL). Numbers in parenthesis after a count denote the frequency of that count. The $4^{\text {th }}$ lateral row scale from behind opercle, above the $4^{\text {th }}$ lateral-line pored scale and $7^{\text {th }}$ lateral-line pored scale, was removed and compared with the corresponding scales of similarsized $P$. filamentosus from Chembarampakkam Lake. Photographs of scales were taken with an Olympus SP570 UZ digital camera using super-macro mode.

\section{Puntius rohani sp. nov.} (Images 1, 2, 3A)

\section{Holotype}

27.iii.2009, 69.0mm SL, Kodayar River drainage, near Mayilar, KWS, Kanyakumari District, Tamil Nadu, India, $8.5052^{\circ} \mathrm{N} \& 77.3015^{\circ} \mathrm{E}, 110 \mathrm{~m}$, coll. S. Prabakaran, ZSI/ SRS F.8336

\section{Paratypes}

26.iii.2009, 1 ex., $72.0 \mathrm{~mm} \mathrm{SL}$, same locality as holotype, ZSI/SRS F.8328; 21.iii.2008, 1 ex., 86.0mm SL, Lower Kodayar River drainage, near Kallar, KWS, $8.5282^{\circ} \mathrm{N} \& 77.3119^{\circ} \mathrm{E}, 360 \mathrm{~m}, \quad \mathrm{ZSI} / \mathrm{SRS}$ F. 8344; 27.iii.2009, 1 ex., 80.0mm SL, Kodayar River drainage, near Vellachithodu, $8.5206^{\circ} \mathrm{N} \& 77.3113^{\circ} \mathrm{E}, 330 \mathrm{~m}$, ZSI/ SRS F.8345; 18.iii.2008, 1 ex., 63.0mm SL, Paralayar River drainage, near Kalikesam, 8.4111 ${ }^{\circ} \mathrm{N} \& 77.3913^{\circ} \mathrm{E}$, $110 \mathrm{~m}$, all coll. S. Prabakaran, ZSI/SRS F.8362; 16.iv.1992, 1 ex., 84.0mm SL, Pamburivaikal River drainage near Manavalakurichi, $8.1695^{\circ} \mathrm{N} \& 77.3141^{\circ} \mathrm{E}, 10 \mathrm{~m}$, ZSI/SRS F.8365; 20.ix.1989, 5 ex., 65.0-85.0 mm SL, Palkulam, Paralayar River drainage, coll. J.C. Dhas, ZSI/SRS F. 8366; 18.ii.2003, 4 ex., 63.0-95.0 mm SL, Keeriparai $8.3958^{\circ} \mathrm{N} \& 77.4097^{\circ} \mathrm{E}, 140 \mathrm{~m}$, / Kalikesam, $8.40873^{\circ} \mathrm{N}$ \& $77.39226^{\circ} \mathrm{E}, 100 \mathrm{~m}$, Paralayar drainage, coll. R.J. Ranjit Daniels \& J.D. Marcus Knight, ZSI/SRS F.7340.

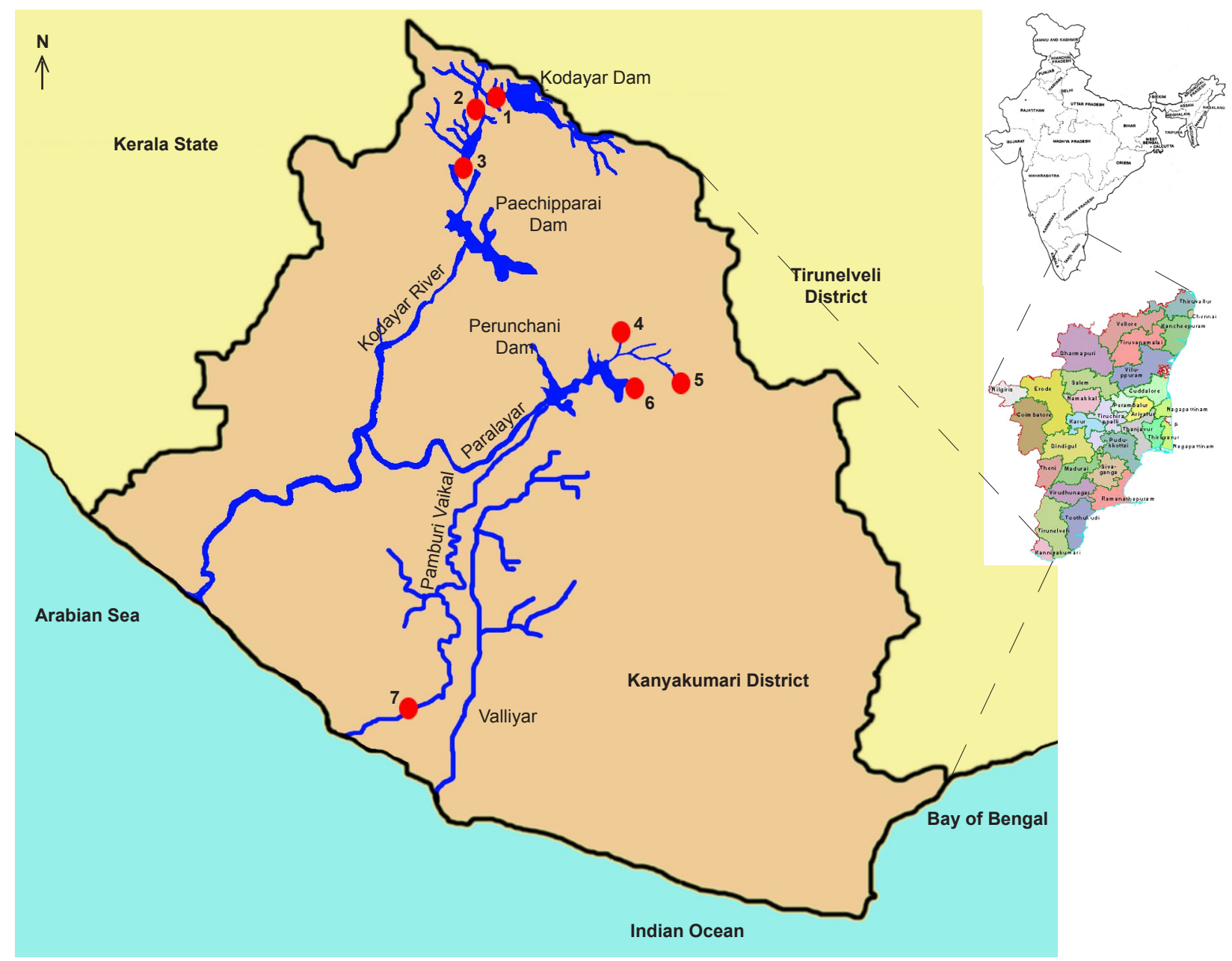

Figure 1. Principal localities in southern India from where Puntius rohani sp. nov. has been collected:

1 - Kallar; 2 - Vellachithodu; 3 - Mayilar; 4 - Kalikesam; 5 - Keeriparai; 6 - Palkulam; 7 - Manavalakurichi (map not to scale). 


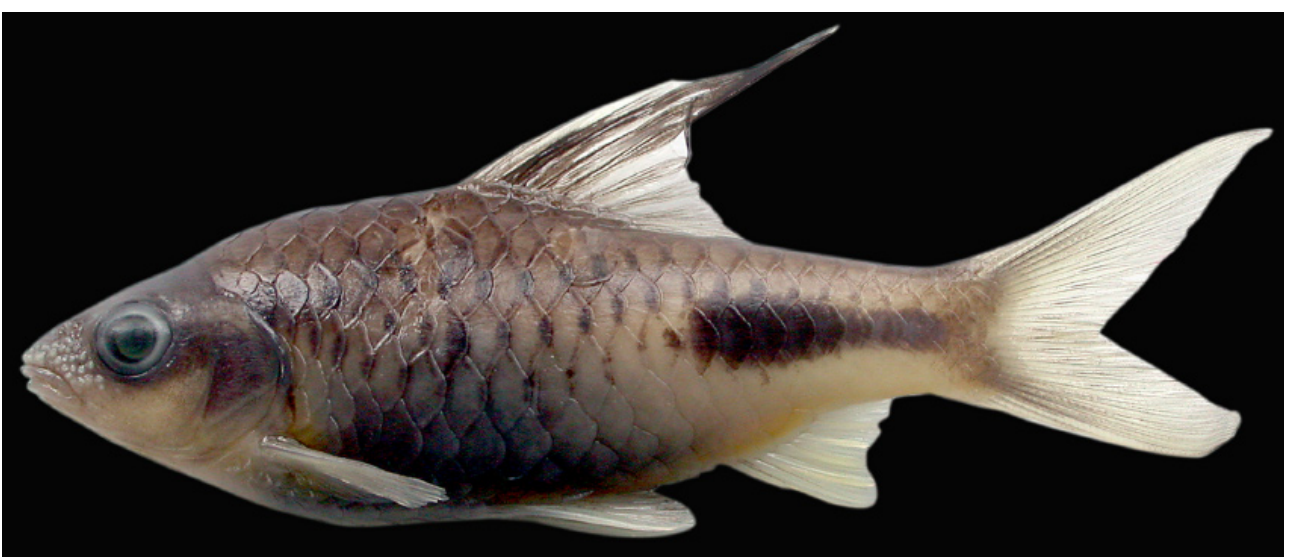

Image 1. Puntius rohani sp. nov. holotype, 69mm SL, ZSI/SRS F.8336.

Table 1. Morphometric data of holotype (ZSI/SRS F.8336) and 15 paratypes (ZSI/SRS F.8336, 7340, 8328, 8344-45, 8362, 8365-66) of Puntius rohani sp. nov.

\begin{tabular}{|l|c|c|c|}
\hline Characters & Holotype & $\begin{array}{c}\text { Paratypes } \\
\text { (N = 15) }\end{array}$ & Mean \pm SD \\
\hline Standard length [mm] & 69.0 & $56.0-95.0$ & \\
\hline \% SL & & & \\
\hline Total length & 138 & $133-139$ & $137 \pm 2$ \\
\hline Head length & 30.8 & $27.9-31.4$ & $29.7 \pm 1.0$ \\
\hline Head depth & 23.4 & $20.3-29.4$ & $23.5 \pm 2.3$ \\
\hline Predorsal length & 47.3 & $46.5-53.1$ & $49.4 \pm 1.9$ \\
\hline $\begin{array}{l}\text { Dorsal to hypural } \\
\text { distance }\end{array}$ & 55.0 & $49.7-56.1$ & $53.0 \pm 1.7$ \\
\hline Maximum body depth & 35.7 & $32.2-39.1$ & $36.3 \pm 2.3$ \\
\hline $\begin{array}{l}\text { Caudal peduncle } \\
\text { length }\end{array}$ & 16.2 & $14.5-17.8$ & $15.8 \pm 1.0$ \\
\hline Maximum body width & 20.7 & $12.4-20.7$ & $15.0 \pm 2.5$ \\
\hline $\begin{array}{l}\text { Caudal peduncle } \\
\text { depth }\end{array}$ & 13.0 & $12.3-18.2$ & $15.2 \pm 1.8$ \\
\hline Maxillary barbel length & 3.6 & $2.5-4.6$ & $3.5 \pm 0.5$ \\
\hline Snout length & 10.1 & $6.9-10.1$ & $8.6 \pm 0.8$ \\
\hline Length of maxilla & 8.6 & $6.8-9.5$ & $8.3 \pm 0.7$ \\
\hline Eye diameter & 8.6 & $7.7-9.4$ & $8.7 \pm 0.4$ \\
\hline Interorbital width & 9.8 & $9.0-11.1$ & $10.2 \pm 0.5$ \\
\hline Internarial width & 6.0 & $5.3-7.4$ & $5.9 \pm 0.5$ \\
\hline $\begin{array}{l}\text { Postorbital head } \\
\text { length }\end{array}$ & 12.3 & $11.2-15.2$ & $13.1 \pm 1.0$ \\
\hline$\%$ HL & 39.9 & $38.9-48.4$ & $44.3 \pm 2.8$ \\
\hline Maxillary barbel length & 11.7 & $8.2-16.0$ & $11.8 \pm 2.1$ \\
\hline Length of maxilla & 28.1 & $23.6-32.0$ & $28.1 \pm 2.0$ \\
\hline Snout length & 32.8 & $23.4-33.9$ & $29.1 \pm 2.7$ \\
\hline Eye diameter & 28.1 & $25.7-32.1$ & $29.4 \pm 2.0$ \\
\hline Interorbital width & 31.9 & $30.9-37.8$ & $34.3 \pm 1.7$ \\
\hline Internarial width & 19.7 & $18.3-23.7$ & $20.1 \pm 1.4$ \\
\hline $\begin{array}{l}\text { Postorbital head } \\
\text { length }\end{array}$ & & & \\
\hline
\end{tabular}

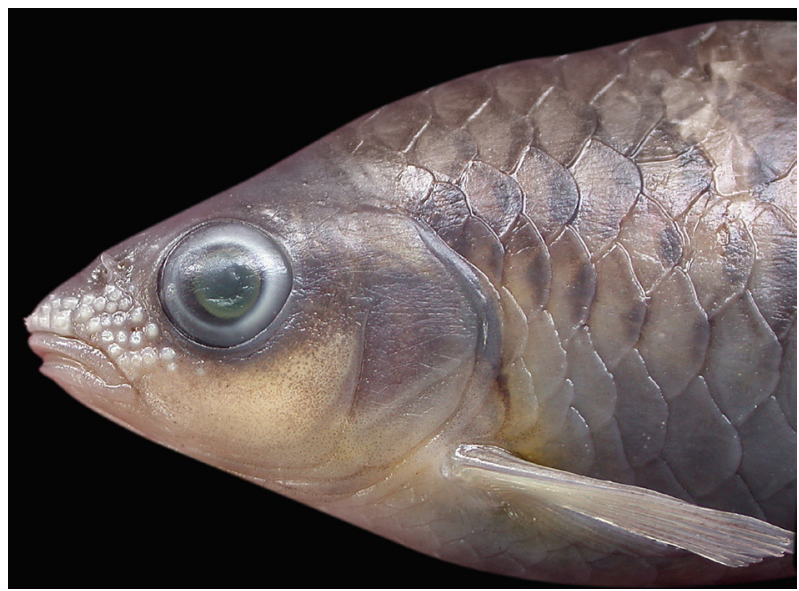

Image 2. Snout of Puntius rohani sp. nov. holotype, $69 \mathrm{~mm}$ SL, ZSI/SRS F.8336, showing dense tuberculation.

\section{Additional material}

20.ix.1989, 19 ex., 54.0-85.0 mm SL, Palkulam, Paralayar River drainage, coll. J.C. Dhas, ZSI/SRS F. 2831.

\section{Diagnosis}

Adults of Puntius rohani are distinguished from all members of the Puntius filamentosus Group sensu Pethiyagoda \& Kottelat (2005a) by their unique colour pattern of a black club-shaped blotch 1.5 scales high extending from the $12-13^{\text {th }}$ lateral-line scales to the caudal-fin base, the absence of any other body colour pattern anterior to it (vs. presence in $P$. arulius (Image 3K), P. tambraparniei (Images 3F,G), $P$. srilankensis and $P$. exclamatio (Image $3 \mathrm{H})$ ), and the absence of a transverse black band near the tip of each caudal-fin lobe (vs. presence in $P$. assimilis (Image $4 \mathrm{~J}$ ) and $P$. filamentosus (Image 3E)).

\section{Description}

Morphometric data of holotype and 14 paratypes 


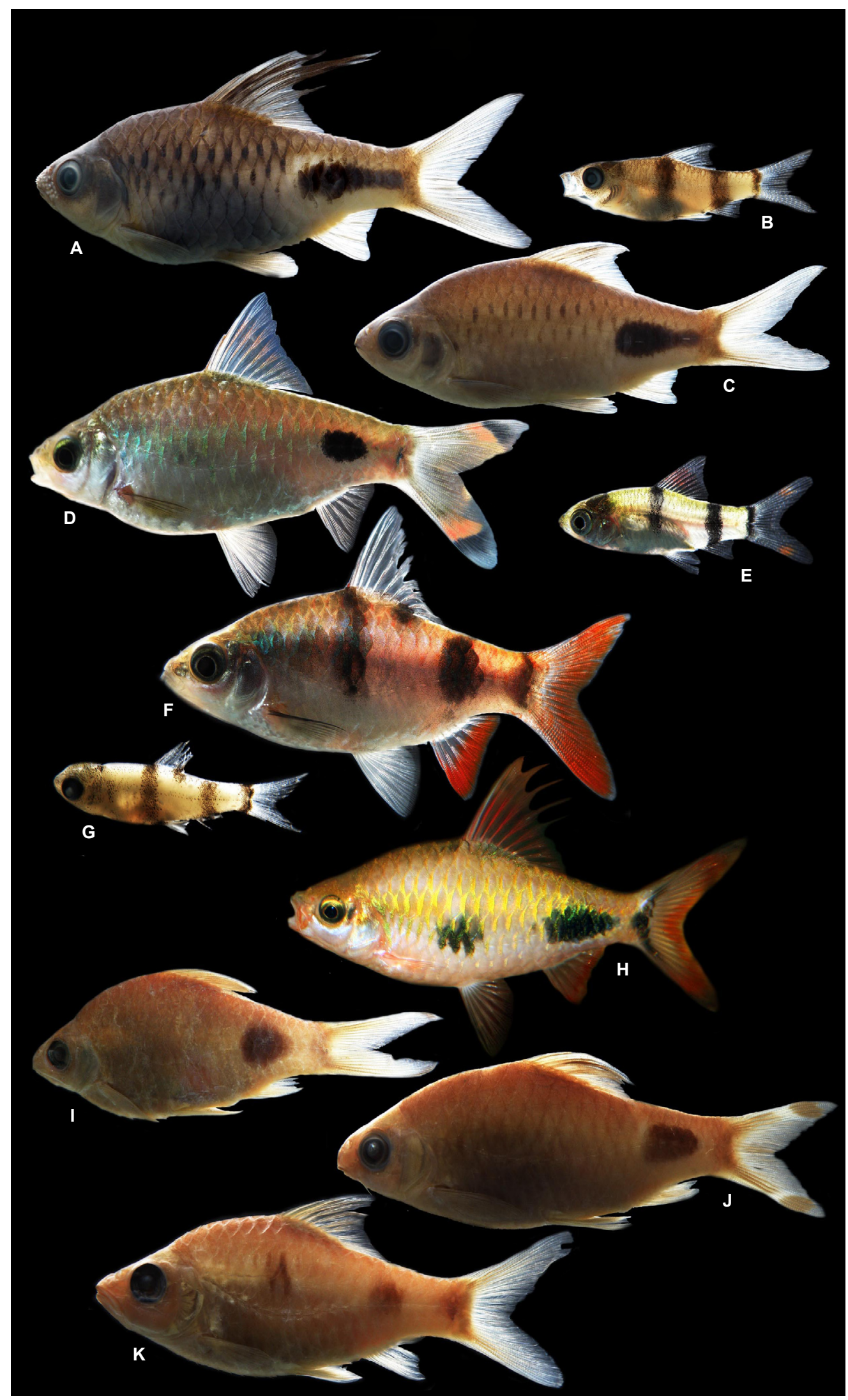

Image 3. A - P. rohani sp. nov. (holotype); B - P. rohani sp. nov. juvenile; C - P. rohani sp. nov. (paratype, ZSI/SRS F.8345, $80 \mathrm{~mm}$ SL); D - P. filamentosus (live specimen, uncatalogued); E - P. filamentosus juvenile (live specimen, uncatalogued); F - P. tambraparniei (ZSI/SRS F.8369, 57mm SL); G - P. tambraparniei juvenile (ZSI/SRS F.8370, 14mm SL); H - P. exclamatio (live specimen, uncatalogued); I, J - P.assimilis (ZSI/SRS F.8371, 84mm SL); K - P. arulius (ZSI/WGRC F.3954, 74mm SL). 
are provided in Table 1. General body shape and appearance as in Images 1 and 3A. Body elongate, laterally compressed; dorsal contour ascending, with a low indentation at nape, slightly convex anterior to dorsalfin origin, tapering gradually ventrad posterior to dorsal-fin inserion; ventral profile equally convex anterior to pelvic-fin origin, curving gently up to anal-fin origin, thence sloping dorsad towards caudal peduncle; caudal peduncle deep, its depth a little less than its length, concave in both dorsal and ventral profiles.

Head length 27.9-31.4 \% SL; eyes large, their diameter $25.7-32.1 \% \mathrm{HL}$, positioned nearer to snout than to opercular margin; interorbital wide, a little less than eye diameter; snout length almost equal to eye diameter; males with well-developed tubercles on snout (Image 2). Mouth small, subterminal; lips thick, maxilla extending almost to anterior border of eye. A pair of maxillary barbels present, 8.2-16\% HL. Dorsal fin inserted nearer to tip of snout than to caudal-fin base, with three simple and $81 / 2$ branched rays (some branched rays extending as filaments in adults), its distal margin slightly concave. Anal fin with three simple and $5 \frac{1}{2}$ branched rays. Pelvic fin with one simple and eight branched rays, its origin slightly posterior to dorsal-fin origin. Pectoral fin with one simple and $13(5)$ or $14(10)$ branched rays. Pectoral and pelvic fins short, not reaching pelvic and anal-fin origins, respectively. Caudal fin with $1+9+8+1$ principal rays, deeply forked, with pointed lobes. Lateral line complete, with 21(6), 22(8) or 23(1) scales on body including one scale on the caudal-fin base. Transverse scales from dorsal-fin origin to mid-ventral scale row $1 / 24+1+3(13)$ $3 \frac{1}{2}(2)$, scales between lateral line and pelvic-fin origin 2(13)-21/2(2). An axillary pelvic scale present. Eighteen circumferential scales (counted as the number of scales around the greatest depth of body beginning from the first scale anterior to dorsal-fin origin), 11(14) or 12(1) circumpeduncular scales. $2(9)-3(6)+6(1), 7(8), 8(5)$ or 9(1) gill rakers on first gill arch.

Colouration: In life, adult specimens greenish above, cream-white underside. Dorsal fin dusky, with traces of red. Pectoral and pelvic fins hyaline. Anal fin bordered with a bright red margin. Caudal fin bright red, lacking markings except for darker colour of principal rays. A dark bluish to black club-shaped marking present on tail, continuing on to principal rays of caudal fin. Formalin-fixed and alcohol-preserved specimens brownish above with a pale yellowish underside. Dorsal fin with branched rays more pigmented than other rays. All other fins creamish. Preserved juveniles express characteristic colouration of $P$. filamentosus group: pale yellow with three black bars on body (Image 3B).

\section{Etymology}

The species is named after Rohan Pethiyagoda, in appreciation of his extensive work on the freshwater fishes of India and Sri Lanka. The species name is formed as a

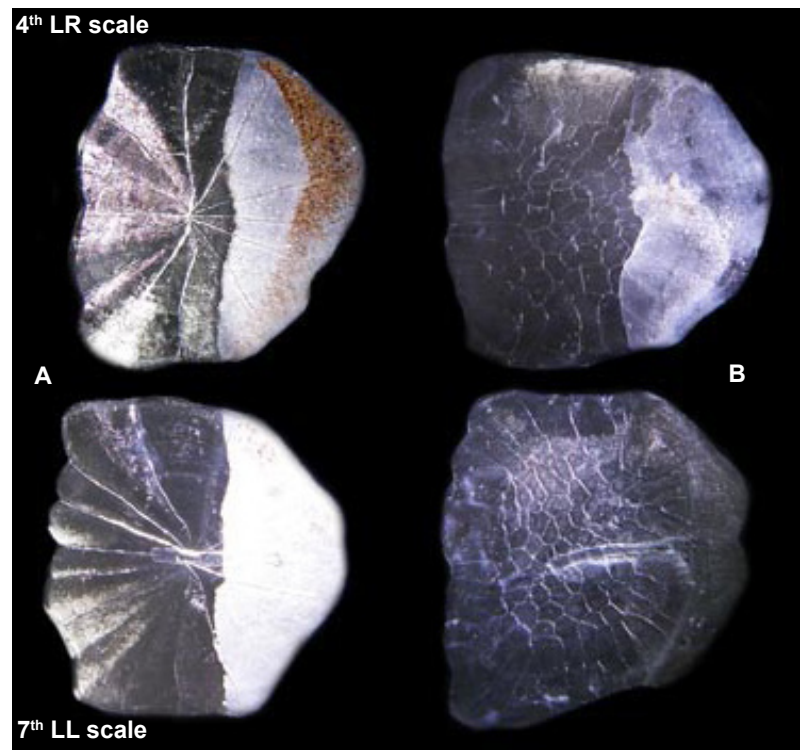

Image 4. $4^{\text {th }}$ Lateral-row scale above $4^{\text {th }}$ lateral-line pored scale (LR) and $7^{\text {th }}$ lateral-line (LL) scales of A - P. rohani; $B$ - $P$. filamentosus, from Chembarampakkam Lake, Tamil Nadu, India.

noun in the masculine genitive singular.

\section{Distribution}

Puntius rohani sp. nov. is at present known only from the hill streams of Kanyakumari District, Tamil Nadu, India, draining into the Arabian Sea (Fig. 1).

\section{DISCUSSION}

Fishes of the genus Puntius (Hamilton, 1822), commonly called barbs, are prolific and known to occupy a broad variety of freshwater niches in tropical Asia (Jayaram 1999). Despite a revision of the genus by Jayaram (1991), several taxonomic problems persisted in the $P$. filamentosus Group until the work of Pethiyagoda \& Kottelat $(2005 a, b)$. One such was the identity of $P$. mahecola, long misidentified or considered a junior synonym of $P$. filamentosus. This resulted in some authors confusing the two species (e.g., Jayaram 1991; Menon 1991; Talwar \& Jhingran 1991). Raj (1916) sought to differentiate the two species by the presence or absence of barbels, and a few other authors too, tried unsuccessfully to resolve this confusion (e.g., Selvaraj \& Abraham 1987), but none referred to the type specimens of the two species and freshly-collected topotypes until Pethiyagoda \& Kottelat (2005b), who showed P. mahecola to be distinct from $P$. filamentosus, and indeed not even closely related. Members of the $P$. filamentosus Group have a characteristic juvenile coloration of three black bars on the body, with adult males having filamentous extensions of their branched dorsal-fin rays.

Until now, the $P$. filamentosus Group has included 


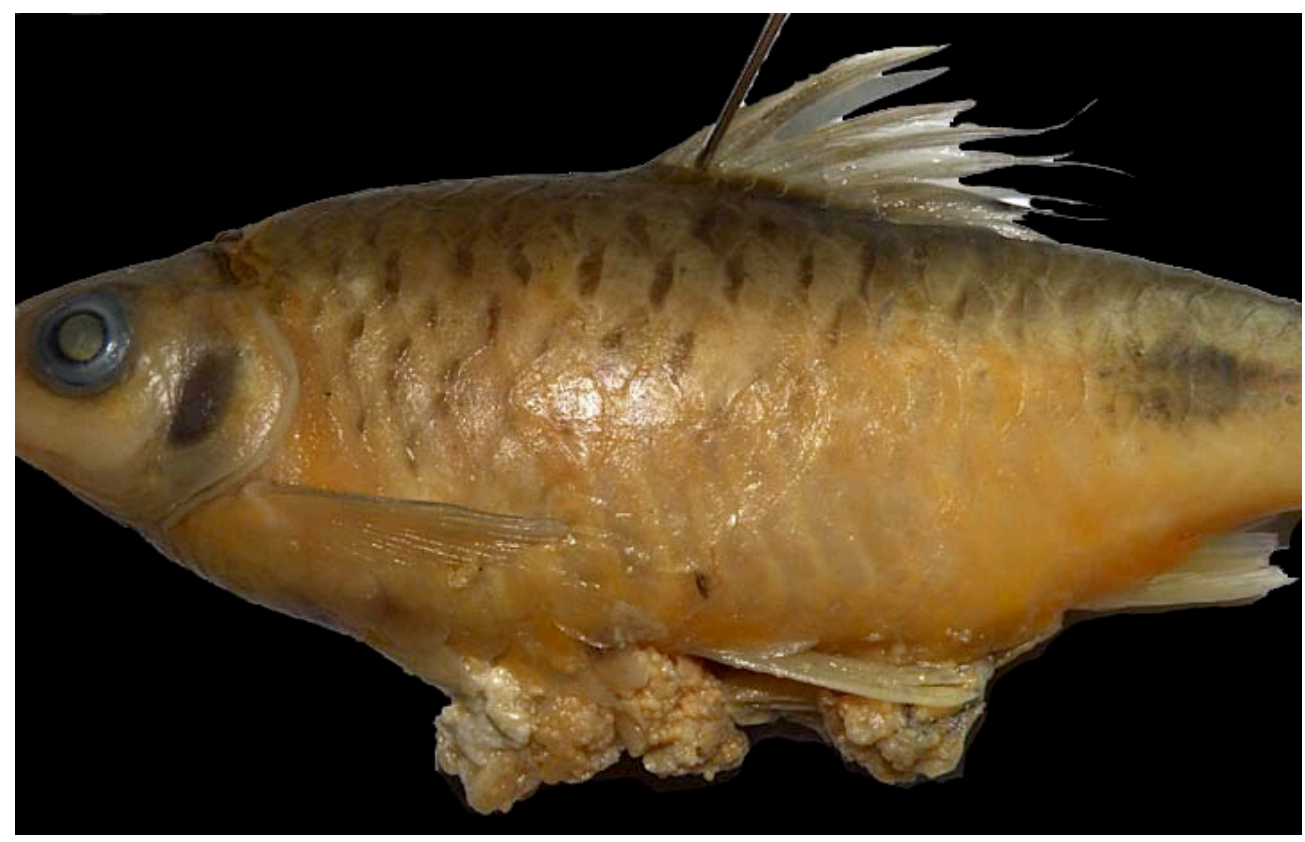

Image 5. Gravid female P. filamentosus (ZSI/SRS F.8368, 113mm SL), showing filamentous extensions of the dorsal fin branched rays.

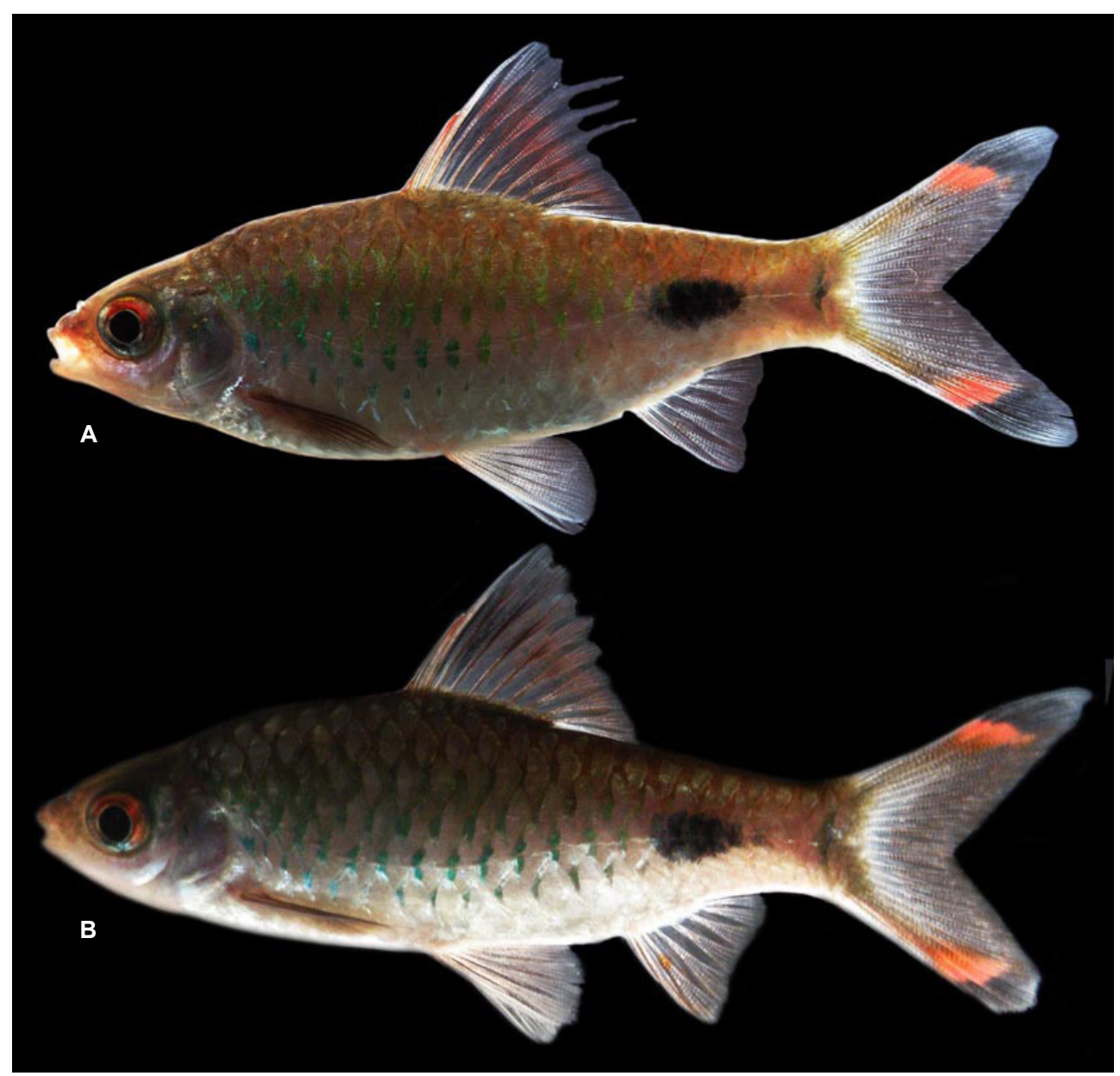

Image 6. A - Male $P$. filamentosus maintained alive in aquaria with filamentous extensions to the dorsal-fin branched rays (5 December 2009); B - the same specimen with the dorsal-fin filaments absorbed (27 May 2010). 


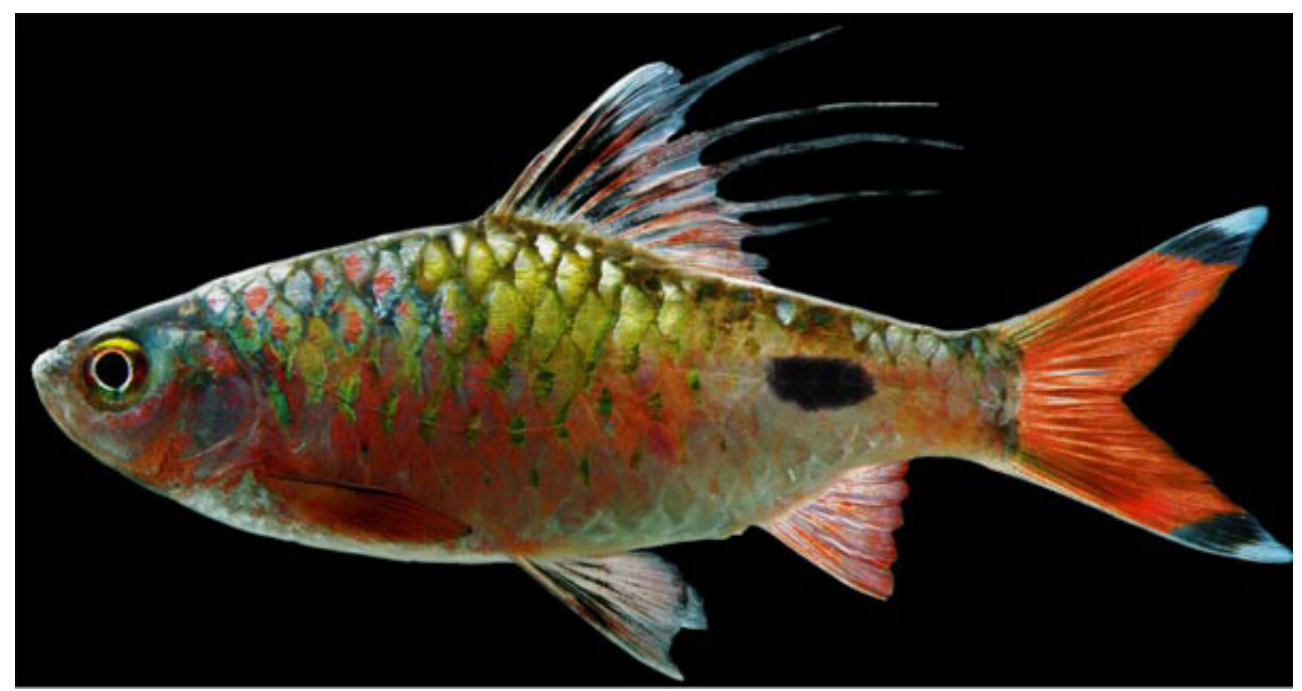

Image 7. Adult male P. filamentosus collected from lakes near Sriperambathur, Tamil Nadu, India (116.0mm SL, ZSI/SRS F.8368).

seven species, two of which ( $P$. singhala and $P$. srilankensis) are endemic to Sri Lanka. We have not in the present study examined Sri Lankan material but have relied on data provided in Pethiyagoda \& Kottelat (2005a). The $4^{\text {th }}$ lateral row scale above the $4^{\text {th }}$ lateral-line scale and $7^{\text {th }}$ lateral-line scale of $P$. rohani sp. nov. was compared with those of $P$. filamentosus collected from Chembarampakkam Lake (Image 4) and found to be very different. The scales of $P$. rohani sp. nov. (3 ex.) have longer and fewer radii meeting at the focus, which is not reticulate, while the scales of $P$. filamentosus (5 ex.) from Chembarampakkam had numerous short radii meeting at a largely reticulated focus.

Indra (1992) published a colour photograph of a barb which she identified as a colour variation of $P$. filamentosus from the Periyakulam Reservoir in Kanyakumari. The same species also featured in the work of Johnson et al. (2007), which compared the genetic variation in different populations of $P$. filamentosus from southern India using restriction fragment length polymorphism (RFLP) analysis. This study showed that the population of $P$. filamentosus in Alancholai, Kanyakumari District, possessed a distinct genetic identity and did not cluster with the other populations studied. The present work shows that the species from Alancholai identified as $P$. filamentosus by Johnson et al. (2007) is in fact a distinct (new) species and not an instance of intraspecific polychromaticism of $P$. filamentosus as it has a shorter interorbital width and a longer maxillary barbel length when compared to $P$. filamentosus. This species is now described as $P$. rohani sp. nov. It has a single pair of well developed maxillary barbels of length $2.5-4.6 \% \mathrm{SL}$ (vs. $0.8-2.2 \% \mathrm{SL}$ in $P$. filamentosus, $0.0-1.3 \% \mathrm{SL}$ in $P$. singhala, and 7.0-10.2 $\% \mathrm{SL}$ in $P$. assimilis). It is also distinguished by having the mouth subterminal (vs. inferior in $P$. srilankensis and $P$. assimilis) and a greater postorbital head length of $11.2-15.2 \%$ SL (vs. 8.2-10.4\% SL in P. assimilis), a shorter caudal-peduncle length of $14.5-17.8 \%$ SL (vs. $17.9-19.9 \%$ SL in $P$. singhala and $18.5-21.4 \% \mathrm{SL}$ in $P$. srilankensis but longer than $P$. arulius, which is 13.1$14.3 \% \mathrm{SL}$ ). It further differs from $P$. srilankensis by its longer head of 27.9-31.4 \% SL (vs. 24.8-26.7 \% SL), and greater body depth of 32.2-39.1\% SL (vs. 28-31.9 $\% \mathrm{SL}$ ). Puntius rohani sp. nov. also has a narrower interorbital width of $9.0-11.1 \%$ SL (vs. 11.2-12.2 \% SL in $P$. filamentosus). It further differs in meristic characters such as lateral line scale count of $21-23+1$ (vs. 18-20 $+1-3$ in P. filamentosus and 19-20 in P. assimilis ), and pectoral fin with 1 simple and 13-14 branched rays (vs. 15 in $P$. arulius, $P$. tambraparniei and $P$. srilankensis). It is likely that the locality name 'Periyakulam' mentioned by Indra (1992) is in fact Palkulam (8.371 $\left.\mathrm{N} \& 77.407^{\circ} \mathrm{E}\right)$, which is in the same west-flowing drainage, close to the type locality, while Periyakulam $\left(10.050^{\circ} \mathrm{N} \& 77.593^{\circ} \mathrm{E}\right)$ is on the Vaigai River, which is an east-flowing drainage in Theni District, more than $200 \mathrm{~km}$ distant from the type locality.

According to Pethiyagoda \& Kottelat (2005a), though $P$. exclamatio belongs to the $P$. filamentosus Group, adult males were not known to have filamentous extensions to their dorsal-fin branched rays. Specimens of $P$. exclamatio (see Image $3 \mathrm{H}$ ) collected from the Kallada River, however, exhibit such filamentous extensions and we speculate that the males examined by Pethiyagoda \& Kottelat (2005a) may have had the extensions absorbed during the season in which they were collected (MarchApril, the end of the dry season in Kerala). Interestingly, during the present study we also encountered a few female specimens of $P$. filamentosus collected from Chembarampakkam Lake $\left(13.000^{\circ} \mathrm{N} \& 80.082^{\circ} \mathrm{E}\right)$ in the outskirts of Chennai, and Vaigai Dam in Theni District, Tamil Nadu, with filamentous extensions of the dorsal- 
fin branched rays (Image 5), which suggests that this character is not always sexually dimorphic. Moreover, we also observed that male $P$. filamentosus maintained in aquaria by the third author shed their dorsal-fin filaments, which grow back after some time (Image 6). We also examined specimens (Image 4I) from the Cauvery River near Bhavani Town, (ZSI/SRS F.79), which resembled $P$. assimilis but had a deeper body, the black band near the caudal fin tips very small and faint, and the shape of the caudal blotch more rounded than elongate (Image 3I). We propose to elucidate the identity of this fish in a subsequent work.

Jerdon (1848) described P. maderaspatensis, which has been considered a synonym of $P$. filamentosus (Pethiyagoda \& Kottelat 2005a). We collected specimens from the lakes around Sriperambathur $\left(12.970^{\circ} \mathrm{N}\right.$ \& $\left.80.031^{\circ} \mathrm{E}\right)$, the type locality of $P$. maderaspatensis. As mentioned by Jerdon (1848), some males from this locality possess bright red caudal fins (Image 7), apart from which they resemble $P$. filamentosus: we too, tentatively treat $P$. maderaspatensis as a synonym of $P$. filamentosus pending further investigation. As stated by Pethiyagoda \& Kottelat (2005a) the waters of Tamil Nadu and Kerala have been inadequately explored. Systematic surveys are likely to add more species to this interesting group of fishes.

\section{Comparative material}

Puntius filamentosus: 03.ii.2010, 4 ex., 84.0$113.0 \mathrm{~mm}$ SL, Vaigai Dam, Vaigai River drainage, ZSI/ SRS F.8367; 12.x.2009, 7 ex., 79.0-116.0 mm SL, Chembarampakkam Lake, Adyar River drainage, all coll. J.D. Marcus Knight, ZSI/SRS F.8368; November 2003, 4 ex., 60.0-74.0 mm SL, Gundia River drainage, Kodagu District, ZSI/SRS F.7630; 12.ii.1998, 1 ex., 122.0mm SL, Aliyar River drainage, ZSI/SRS F.5611; 24.ii.1998, 53 ex., 59.0-107.0 mm SL, Amaravathi Dam, Amaravathi River drainage, ZSI/SRS F.5664; 25.ii.1998, 34 ex., 63.0109.0 mm SL, Punganodai, Amaravathi River drainage ZSI/SRS F.5676; 26.ii.1998, 15 ex., 69.0-110.0 mm SL, Kuduthurai, Bhavani River drainage, ZSI/SRS F.5689; 27.ii.1998, 1 ex., 37.0mm SL, Thirumurthi Dam, Palar River drainage, ZSI/SRS F.5710; 28.ii.1998, 8 ex., 30.0$39.0 \mathrm{~mm}$ SL, Navalodai, Amaravathi River drainage, all coll. M.S. Ravichandran, ZSI/SRS F.5726; 18.ix.2006, 1 ex., 23.0mm SL, Farangipet, Nethravathi River drainage, coll. S. Prababkaran, ZSI/SRS F.7962; 11.ii.1996, 4 ex., 100.0mm SL, Aliyar canal, Aliyar River drainage, ZSI/ SRS F.4908; 11.ii.1996, 14 ex., 85.0-135.0 mm SL, Thirumurthi Dam, Palar River draiange, ZSI/SRS F. 4911; 08.ii.1996, 1 ex., 45.0mm SL, Kallapuram, Amaravathi River drainage, ZSI/SRS F.4931; 13.viii.1997, 1 ex., $38.0 \mathrm{~mm}$ SL, Devikulam, Chinnar River drainage, ZSI/ SRS F.5320; 15.viii.1997, 1 ex., 36.0mm SL, Valparai, Chalakudi River draiange, ZSI/SRS F.5337; 16.viii.1997, 1 ex., 15.0mm SL, Aliyar, Aliyar River drainage, ZSI/SRS
F.5392; 18.xii.1997, 1 ex., 135.0mm SL, Amaravathi Dam, Amaravathi River drainage, ZSI/SRS F. 5430; 09.viii.1997, 1 ex., 55.0mm SL, Kozhumam, Amaravathi River drainage, ZSI/SRS F.5342; 09.viii.1997, 1 ex., 34.0mm SL, Kallapuram, Amaravathi River drainage, all coll. M.B. Raghunathan, ZSI/SRS F.5351.

Puntius tambraparniei: 11.i.2010, 1 ex., 57.0mm SL, Tamiraparani River drainage, ZSI/SRS F.8369; 11.i.2010, 1 ex., 14.0mm SL, Tamiraparani River drainage, all coll. J.D. Marcus Knight, ZSI/SRS F.8370; 09.i.1995, 3 ex., 39.0-67.0 mm SL, Maradur Anicut, Tamiraparani River drainage, coll. Mary Bai, ZSI/SRS F.8371; 09.iv.1994, 4 ex., 44.0-128.0 mm SL, Sankaran Koil, Tamiraparani River drainage, coll. M.S. Ravichandran, ZSI/SRS F.4232; 19.iv.1994, 1 ex., 35.0mm SL, near Cheramadevi, Tamiraparani River drainage, ZSI/SRS F.4202; 09.iv.1995, 20 ex. 55.0-90.0 mm SL, Papanasam, Tamiraparani River drainage, all coll. M.B. Raghunathan, ZSI/SRS F.4452.

Puntius cf. assimilis: 09.iv.1973 / 15.ii.1979, 9 ex., 40.0-84.0 mm SL, Cauvery River drainage near Bhavani Town, coll. K.C. Jayaram, labelled as $P$. filamentosus, ZSI/SRS F.79.

Puntius assimilis: 02.iv.1992, 6 ex., 60.0-98.0 mm SL, Athirapally Falls, Chalakudi River drainage, coll. K.B. Jegadeesh \& R. Kannan, ZSI/SRS F.8372.

Puntius arulius: 07.xii.1985, 1 ex., 74.0mm SL, Bhavani River drainage, Coorg District, Karnataka, ZSI/ WGRC F.3954; 10.iii.1990, 3 ex., 65.0-80.0 mm SL, Mavanahalla, Moyar River drainage, Coorg District, Karnataka, all coll. K.N. Nair, ZSI/WGRC F.5077; 2 ex., 74.0-96.0 mm SL, Kabini River, (date: unknown), coll. R.S. Lal Mohan, ZSI/SRS, F.8373.

\section{REFERENCES}

Day, F. (1878). The fishes of India; being a natural history of the fishes known to inhabit the Seas and Freshwaters of India, Burma and Ceylon. Bernard Quaritch, Piccadilly London, xx+778pp, 196pls.

Hamilton-Buchanan, F. (1822). An Account of the Fishes of River Ganges and its Branches. George Ramsay and Co., London, vii+405pp, 39pls.

Indra, T.J. (1992). Report on the ichthyofauna of Kanyakumari District, Tamil Nadu. Records of the Zoological Survey of India 92: 177-192.

Johnson, J.A., R.P. Rajesh, L.A. Mary \& M. Arunachalam (2007). Comparative analysis of inter population genetic diversity in Puntius filamentosus using restriction fragment length polymorphism (RFLP) analysis. African Journal of Biotechnology 6(23): 2682-2686.

Jayaram, K.C. (1991). Revision of the genus Puntius (Hamilton) from the Indian Region (Pisces: Cypriniformes, Cyprinidae, Cyprininae). Records of the Zoological Survey of India, Occasional Paper 135: 1-178.

Jayaram, K.C. (1999). The Freshwater Fishes of the Indian Region. Narendra Publishing House, New Delhi, 551pp.

Jerdon, T.C. (1848-49). On the freshwater fishes of southern India. Madras Journal of Literature and Science, 15 (1848): 141-149; 15 (1849): 302-346.

Menon, A.G.K. (1999). Check list - fresh water fishes of India. 
Records of the Zoological Survey of India, Miscellaneous Publication, Occasional Paper No. 175, 366pp.

Pethiyagoda, R. \& M. Kottelat (2005a). A review of the barbs of the Puntius filamentosus group (Teleostei: Cyprinidae) of Southern India and Sri Lanka. Raffles Bulletin of Zoology Supplement 12: 127-144.

Pethiyagoda, R. \& M. Kottelat (2005b). The identity of the south Indian barb Puntius mahecola (Teleostei: Cyprinidae). Raffles Bulletin of Zoology Supplement 12: 145152.

Raj, S.B. (1916). Notes on the freshwater fish of Madras. Records of the Indian Museum XII(VI): 249-294.

Selvaraj, C. \& M. Abraham (1987). Review of the taxonomic status of Puntius mahecola (Valenciennes). Matsya 12\&13: 20-25.

Talwar, P.K. \& A.G. Jhingran (1991). Inland Fishes of India and Adjacent Countries. Vol 1. Oxford \& IBH Publishing Co. Pvt. Ltd., New Delhi, Bombay, Calcutta, 541pp.
Author Details: K REMA DEVI is a senior scientist in the Southern Regional Centre of the Zoological Survey of India and an ichthyologist who has published over hundred papers including descriptions of several new species. T.J. INDRA is a senior scientist in the Southern Regional Centre of the Zoological Survey of India and an ichthyologist and also a specialist on scorpions. She has published several papers including descriptions of new species.

J.D. MARCUS KNIGHT is a naturalist based in Chennai. Amongst others, his interest is in exploring the freshwater habitats and is currently documenting the diversity of freshwater fish in and around Chennai, Tamil Nadu.

Author Contributions: KRD carried out the morphometric study of the new species. TJI was the first to report this species in the year 1992 and has provided specimens for the present study. JDMK also provided specimens for study. He has studied the Puntius filamentosus of Tamil Nadu, specially the ones around Chennai for the past two years. All observations regarding Puntius filamentosus maintained in aquariums and all photographs except those acknowledged for were provided by him. 